\title{
Working Time Perception Influence on Employees' Work Satisfaction - Revisiting Dispositional Approach on Employees' Satisfaction
}

\author{
Umar BAIHAQKI, Meila Riskia FITRI and Wulan A. KHAIRUNISA
}

Universitas Negeri Jakarta, Jakarta, Indonesia

Correspondence should be addressed to: Umar BAIHAQKI; umar_baihaqki @unj.ac.id

Received date: 3 July 2020; Accepted date: 4 January 2021; Published date: 25 January 2021

Academic Editor: Afshan Rauf

Copyright (C) 2021. Umar BAIHAQKI, Meila Riskia FITRI and Wulan A. KHAIRUNISA. Distributed under Creative Commons Attribution 4.0 International CC-BY 4.0

\begin{abstract}
Employee is adapting with their working environment. As part of work arrangement, working time is an important factor that determines how employees perceive their working life. This research composes working time perception as a complex variable that is measured in four dimensions, including discipline, incentive, knowledge, and commitment. We construct a hypothesis that working time perception positively and linearly influences employees' work satisfaction. Based on a survey of 320 employees, the results of linear regression analysis confirm the validity of this hypothesis. We conclude that employees who are bounded by their work setting would have a fairly work satisfaction when they perceived their working hours positively.
\end{abstract}

Keyword: working time, work satisfaction, individual trait, dispositional theory.

\section{Introduction}

One of the objective factors in the work setting arrangement is working time. Time in its relation to work is meaningful for employees. Working time is more than just hours spent for work, it is also perceived by employees as a social setting that intervenes their personal life (Henly \& Lambert, 2014; Okulicz-Kozaryn \& Golden, 2018; Olsson \& Sundh, 2019). Working time shapes workers' experience and influences their productivity (O'Carroll, 2015; KÜnn-Nelen. De Grip. And Fourarge, 2013; Azwir dan Satriawan, 2018). Work setting 
arrangement modifies the working environment for employees to adapt when workers fulfill their obligations at work (Goodarzi, Nurmi, \& Rantanen, 2015).

There are two groups of interest regarding the working time arrangement in organization. The employer arranges work hours in their favor to generate maximum production output, which makes them prefer longer working hours. On the other hand, the employees prefer shorter working time so that they can have more time to arrange their personal life and well-beings (Vielers, Münderlein, and Koster 2013; Garnero, Kampelmann, and Rycx, 2014). These two opposite interests are not symmetrical, where the employer has a better bargaining position and the employee is in the position to comply (O'Carroll, 2015; Watson, 2008: 246).

Manager needs to be careful in determining working time for employees. Several studies on working time conclude that working time has a nonlinear correlation with productivity (Beherens, 2013; Bannai and Tamakoshi, 2014). Employees' working time only supports productivity rate until a certain turning point where adding more work time would be counterproductive. Excessive working time is hazardous to employees' health and also becomes one of the occupational stress factors that cause anxiety. Long working hours could generate health issues because employees do not have enough time to rest, which increases the possibility to fall sick and forces them to absence from their work (Nätti, Oinas, \& Anttila, 2015). This issue could harm organizational productivity due to employees' absence because of health reasons. Prolonged work hours and excessive workload also raised the psychological risk of employees (Boschetto, De Rosa, \& Marini, 2016). Long work hours increase the work-family conflict which reduce the ability of the employees to focus on what they are doing in the organization (Burchielli et al., 2008; Olsson \& Sundh, 2019; O'Carroll, 2015). Therefore, working time is not a one-dimensional concept, and it is more useful to understand work hours from the employees' perspective.
Employees' responses to work time arrangements vary according to their unique experience. Thus, it becomes important to discuss the effect of working time on job satisfaction. Ideally, the ideal working time is 8 hours a day (Bannai and Tamakoshi, 2014), but in fact employees often spend longer than this time in the office. The working arrangement may also encourage employee to complete the work on time by providing incentives. Accordingly, the goals or targets of the organization could be achieved effectively and efficiently.

The part-time employee and the full-time employee have a different way to perceive working time in this sense. For part-time employees, especially those who are paid based on their working time, they tend to work extra hours to get more income (Henly \& Lambert, 2014; KÜnn-Nelen. De Grip. And Fourarge, 2013; Münderlein, and Koster, 2013; Garnero, Kampelmann, \& Rycx, 2014; Baihaqki \& Jahja, 2019). Meanwhile, fulltime employees with a fixed income prefer shorter working time. They perceive working time as a part of their workload, and would prefer to outsmart their work setting to reduce the workload by taking leave, absence from the office, or even resign from work (Surachman, 2016; Nätti, Oinas, \& Anttila, 2015; Ruppanner \& Maume, 2016). These two statements portray the subjectivity of the understanding of work time arrangements by workers. It is also helpful to use the dispositional theory to explain the personal characteristics of workers, alter their perception of work arrangements, and how the perception affects their job satisfaction. (Peng \& Mao, 2015; Judge, Bono, \& Locke, 2000; Cropanzano, James, \& Konovsky, 1993).

Dispositional theory sees individual behavior influences worker behavior. This research describes the individual as a worker who perceives his/her working time regarding work satisfaction. This view leads them to the strategy of finishing the job within a certain time. Regarding working overtime, employees consider that they will receive rewards, namely incentives and more knowledge. The reward then affects their work satisfaction because it is obtained from the success of 
managing self-esteem, being confident in their skill and being able to control the situation in the form of pressure from supervisors (Mitchell, Smyser, \& Weed, 1975; Ford \& Collinson, 2011), team members (Frazier, et al, 2015; Zhai, Lindorff \& Cooper, 2013), as well as the working time (Okulicz-Kozaryn \& Golden, 2018). Therefore, this article continues to elaborate the impact of employees' working time on their satisfaction.

\section{Personal Trait and Work Satisfaction}

Social environments nurture personality traits through social relations. Work setting creates a certain environment that is intended to influence employees' behavior (Goodarzi, et al, 2015). The Worker adaptation to the dynamic of their work setting in the organization varies according to their personal traits. Dispositional theory explains the importance of personality trait to regulate the mood of an individual toward his/her environment. Several studies have used this theory to explain the relationship between employees' personality as a factor of their work satisfaction. The first group of study focuses on self-determination as an internal drive of individual action that supports the employee's approach to adapt to organizational change. (Shogren, et al, 2015). Self-determination is an autonomous desire to actualize his/her interest that is driven by personal disposition. The next group of study puts more attention on the organization as a dynamic environment that influences workers' wellbeing (Frazier, et al, 2015). Workers consciously evaluate their attachment to the organization, including their trust and confidence of the fulfillment of their personal interest through organization (Frazier, et al, 2015; Peng \& Mao, 2015). The workers use self-efficacy to evaluate their position in the organization in response to organizational treatment. A worker who is personally fit to his/her organizational environment has higher job satisfaction than the one who continuously struggles to adapt with the work setting (Peng \& Mao, 2015). Judge et al (2000) have elaborated self-core evaluation of individual employees as a variable that influences employees' work satisfaction into four dimensions: self-esteem, self-efficacy, locus of control, and neuroticism (Judge, Bono \& Locke, 2000: 237).

Working life build self-esteem to the worker by giving a sense of identity according to their role in society (Grint \& Nixon, 2015; Baihaqki \& Jahja, 2019). However, the meaning of work for an individual also depends on how they perceive their role in the job they are working on. Employee evaluates their role in an organization, as they are driven to engage in the accomplishment of organizational objectives (Nencini, Romaioli, \& Meneghini, 2016), and the social relationship with their colleagues (Zhai, Lindorff \& Cooper, 2013).

Self-Efficacy also plays an important role in job satisfaction. Employees are actualizing themselves through their work, therefore person job-fit would improve their commitment to the job and cope with other demands from outside of their organization life (Peng \& Mao, 2015). The highperformance working system stated that a certain amount of discretion would benefit employees and increase their performance, and thus their satisfaction (Bartling, Fehr, \& Schmidt, 2013; Okulicz-Kozaryn \& Golden, 2018). Employees perceive that they have an acceptable locus of control which makes them able to control what is important in their working life (Mitchell, Smyser, \& Weed, 1975).

\section{Working Time Arrangement}

Modern organizational management aims to create a competitive production process. Organization management uses flexible work arrangements to cope with the liberal competition. These flexible arrangements could be classified into functional flexibility and numerical flexibility (Peetz, 2019). Functional flexibility refers to managerial settings that treat employees as an active resource able to develop themselves. Employers start to intensify the workload of their employees. They manage human resources so that their employees are ready to adapt to a variety of workloads. Numerical flexibility puts the number of workers or the hours they work according to the needs of the organization. Employers arrange the remuneration system for their 
employees to pursue efficiency. Hourly wages and overtime wages are replaced by periodic full-paid incentives. This system benefits employers because they do not need to pay employees who have to work overtime to finish their tasks. The productivity expectations of the employee who has received benefits have also increased. Thus, employees perceive working time as part of the workload because it relates to the incentives they receive.

Working time perception is not a single dimensional concept, such as the amount of time spent to work; this notion is perceived differently by the employer and the employee. For employers, working time is a variable of productivity, whereas increasing or reducing work hours would influence the production output. Employers may give incentives for their employees to work extra time. The high-performance management system suggests discretion for employees in completing an extensive workload (Bartling, Fehr \& Schmidt, 2013). To maintain employees' motivation, management also provides a relatively huge benefit for employees who can achieve their given target. This work arrangement is aimed to nurture self-motivation from the employee to be responsible for their achievement, as employees may need more time to finish their task. Therefore, they voluntarily work overtime so that they would get the full benefit from completing their task.

Employees perceive working time as part of their workload, thus the number of work hours also influences their work satisfaction (Boschetto, De Rosa, \& Marini 2016; O'Carroll, 2015). They realized that their labor is paid from their productivity, and the number of hours they spend working are one of the bases to value their performance. They perceive that having more working hours could generate more income for them (Vielers, Münderlein, \& Koster, 2013; Wanroy \& Wilson, 2006). However, allocating their time to work would reduce the time for their other needs, namely for their family life and recreation. Thus, spending more time for work is considered as a determinant factor that generates work to family conflict, since work has taken most of the time to maintain the employee's family life (Yeh, 2015; Clark, et al, 2014; Voydanoff, 2014; Kelly, et al, 2014). To reduce the risk of work to family conflict, one should compartmentalize their organizational life and family life strictly.

Spending more time to work also increases employees' fatigue which increases the risk for employees' health and their psychological distress. Overworking and being unable to refresh their physical and psychological condition are also known factors for depression and physical illness, that force employees to take absence for health reason (Nätti, Oinas, \& Anttila, 2015; Bannai \& Tamakoshi, 2014). Another reason for working hours becoming a stressor factor is because they generate work-family conflict for the worker (Yeh, 2015; King, et al, 2014; Voydanoff, 2014). However, it is not always the case that shorter work hours would guarantee less work-family conflict as concluded by Ruppanner \& Maume who stress the presence of an individualistic cultural ideology that interferes in how workers balance their time for organization and family (Ruppanner \& Maume, 2016). Long work hours make workers seek an adaptive strategy for balancing their organization life and family life (Hill, Märtinson, \& Ferris 2004).

\section{Method}

Previous research studies have proven a non linear relationship between working time and productivity. Departing from these assumptions, this study intends to see the significance of the linear relationship model between perceptions of working time and job satisfaction. Our hypothesis is that the working time perception influences work satisfaction in a linear fashion. To test the validity of this model, we use linear regression analysis. Data collection was carried out by survey method.

The respondents involved in this survey are those who have worked more than 12 months. They are employees who work in government or private institutions with a formal working agreement. Therefore, all the respondents have a salary above the 
official minimum payment in the city and considered as a middle income. Respondents were recruited using snowball sampling technique. They were given the online questionnaire link via their social media accounts.

Respondents are given questions with four response categories coded in number 1 through 5 which are as follow: $1=$ very low, 2 = low, 3 = fair, 4 = high, $5=$ very high. From their responses, we built a linear relationship model between the two variables. We obtained 320 respondents who met the criteria, namely working in a formal organization with more than one year of work experience in their current workplace.

$\mathrm{X}=(\Sigma X d 1 i)+(\Sigma X d 2 i)+(\Sigma X d 3 i)+(\Sigma X d 4 i)$
The working time perception variable is measured from employees' perception of the work hours at their workplace. Dispositional theory suggests that every individual is driven by their personality traits. Employees who fit with the working time arrangement as part of the work setting in their organization perceived the official work hours positively. The worktime perception variable value is composed of the four dimensions, which include: Work time discipline (Xd1), Work time incentive (Xd2), Work time knowledge (Xd3), and Work time commitment (Xd4). The work time perception index is obtained with the following equation:

The respondents were given questions as follows:

Table 1: Instrument validity test for working time perception variable

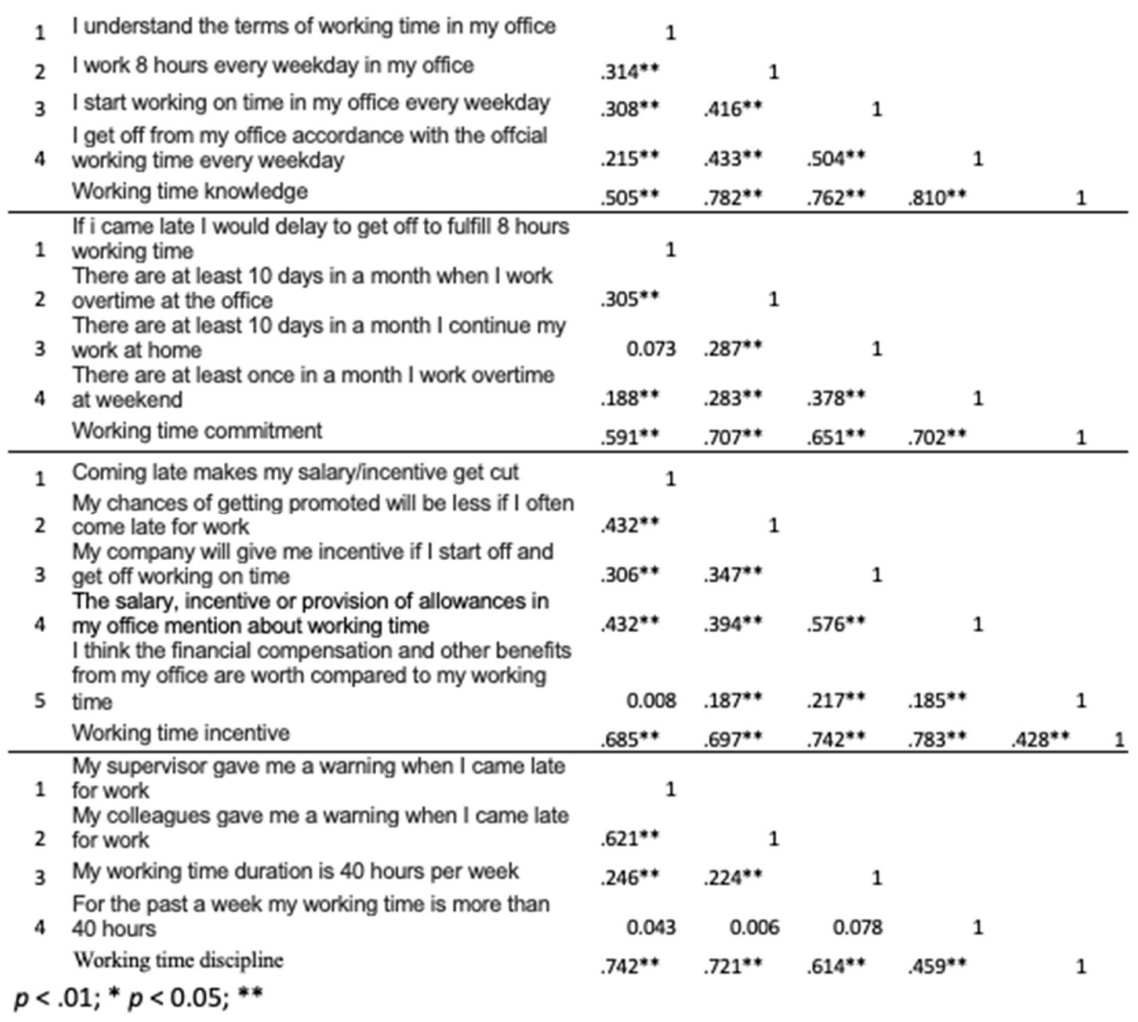


The dependent variable in this study is job satisfaction. We follow the work of Timothy Judge in describing employee work satisfaction perception into four dimensions of personal traits, including self-esteem, self-efficacy, locus of control, and neuroticism. The measurement elaborated into four-dimension variables, which include: Self Esteem, (Yd1), Selfefficacy (Yd2), Locus of control (Yd3) and neuroticism (Yd4). The job satisfaction index obtained by the following equation:

$\mathrm{Y}=(\Sigma Y d 1 i)+(\Sigma Y d 2 i)+(\Sigma Y d 3 i)+(\Sigma Y d 4 i)$

Table 2: Instrument validity test for work satisfaction variable

\begin{tabular}{|c|c|c|c|c|c|c|c|c|}
\hline 1 & I proud of myself when I finish my tasks on time & 1 & & & & & & \\
\hline 2 & I proud of myself when my boss recognize my job & $.427 * *$ & 1 & & & & & \\
\hline 3 & $\begin{array}{l}\text { For me what I do at the office shows who I am } \\
\text { I am ready with the consequences if I failed to finish }\end{array}$ & $.339^{* *}$ & $.427^{* *}$ & 1 & & & & \\
\hline 4 & $\begin{array}{l}\text { Iam ready with the consequences if I failed to finish } \\
\text { my job properly }\end{array}$ & $.246 * *$ & $.187^{* *}$ & $.308^{*}$ & 1 & & & \\
\hline \multirow[t]{2}{*}{5} & I think I deserve to occupy my current position & $.161^{* *}$ & $.386^{* *}$ & $.373^{* *}$ & $.231^{* *}$ & 1 & & \\
\hline & Self esteem & $.596 * *$ & $.716^{* *}$ & $.735 * *$ & $.616^{* *}$ & $.669^{* *}$ & 1 & \\
\hline 1 & I am qualified to carry out my job at the office & 1 & & & & & & \\
\hline 2 & $\begin{array}{l}\text { I can guide other colleagues to complete my routine } \\
\text { tasks }\end{array}$ & $.499^{* *}$ & 1 & & & & & \\
\hline 3 & I deserve to get a promotion & $.538^{* *}$ & $.501 * *$ & 1 & & & & \\
\hline 4 & $\begin{array}{l}\text { I have my own method to work effectively and } \\
\text { efficiently } \\
\text { My works have received recognition from my }\end{array}$ & $.549 * *$ & $.373^{* *}$ & $.487^{* *}$ & 1 & & & \\
\hline 5 & boss/supervisor & $.431^{* *}$ & $.392^{* *}$ & $.454^{* *}$ & $.426 * *$ & 1 & & \\
\hline \multirow[t]{2}{*}{6} & My works have become a reference in my office & $.458^{* *}$ & $.403^{* *}$ & $.431 * *$ & $.421 * *$ & $.593^{* *}$ & 1 & \\
\hline & Self efficacy & $.762 * *$ & $.724^{* *}$ & $.722 * *$ & $.701 * *$ & $.751^{* *}$ & $.748 * *$ & 1 \\
\hline 1 & I can adjust the rythm of my work & 1 & & & & & & \\
\hline 2 & I have never submitted my work over the deadline & $.423^{* *}$ & 1 & & & & & \\
\hline 3 & I can lead other colleagues in a team work & $.280^{* *}$ & $.242^{* *}$ & 1 & & & & \\
\hline 4 & I can decide my own whenever I start working & $.238 * *$ & 0.046 & $.186 * *$ & 1 & & & \\
\hline \multirow[t]{2}{*}{5} & I have the flexibility to complete my tasks & $.352^{* *}$ & $.151^{* *}$ & $.171^{* *}$ & $.515^{* *}$ & 1 & & \\
\hline & Locus of controll & $.674^{* *}$ & $.561^{* *}$ & $.566 * *$ & $681^{* *}$ & $.700 * *$ & 1 & \\
\hline 1 & I feel anxious when my work have not finished yet & 1 & & & & & & \\
\hline 2 & $\begin{array}{l}\text { I feel nervous with my colleagues judgments on my } \\
\text { work } \\
\text { I feel nervous with my supervisor judgments on my }\end{array}$ & $.363^{* *}$ & 1 & & & & & \\
\hline 3 & $\begin{array}{l}\text { Hoerk nervous with my supervisor juagments on my } \\
\text { work }\end{array}$ & $.366^{* *}$ & $.735 * *$ & 1 & & & & \\
\hline 4 & I feel bad whenever I come late to work & $.280^{* *}$ & $.192^{* *}$ & $.239 * *$ & 1 & & & \\
\hline 5 & $\begin{array}{l}\text { Getting off earlier from office's working hour make } \\
\text { myself uneasy }\end{array}$ & $.201 *$ & $.166^{* *}$ & $.175^{* *}$ & $.416^{* *}$ & 1 & & \\
\hline \multirow[t]{2}{*}{6} & My emotional balance is not affected by my work & 0.082 & 0.09 & 0.051 & $.152^{* *}$ & $.184 * *$ & 1 & \\
\hline & Neuroticism & $.578^{* *}$ & $.683^{* *}$ & $.686 * *$ & $.634^{* *}$ & $.622 * *$ & $.445 * *$ & 1 \\
\hline
\end{tabular}

Product moment correlation is used to test the validity of each question to measure both test variables. The validity test result shows that all items are valid and included in the index variables equation. A regression test is used to verify the relationship model between the two test variables, that employees working time perceptions influence their work satisfaction. The regression test includes three statistical assumptions, including normality test to ensure the variants of collected data are distributed normally; linearity test of the two test variables to verify the best model to depict the relationship between work time perceptions and work satisfaction. 
Table 3: Instrument Reliability Test

\begin{tabular}{|c|l|}
\hline Variable & Cronbach Alfpha \\
\hline Work Time Perception & 0.8 \\
\hline Work Satisfaction & 0.8 \\
\hline
\end{tabular}

$p<.01 ;^{*} p<0.05 ;^{* *}$

\section{Finding and Discussion}

Workers have a low perception of their work time. However, the elaboration in the perception of work time variables shows the variation of values in its four dimensions. Measurement of the perception of work time is divided into four dimensions. Workers who have a good work time discipline are punctual in starting work and returning from work. Their knowledge of the detailed regulations regarding their working time is also high. However, they tend to take for granted responding to work time. They do not question the details of working time regulations in their respective institutions. However, workers are aware of the incentives provided by their offices concerning work time. They also realize that the remuneration system in their office no longer provides an incentive for working extra time. Thus, their commitment to completing work outside office hours is low. This particular finding supports the conclusion from the previous study that suggests workers prefer shorter work hours.

Table 4: Test Variable Dimensions Index Values

\begin{tabular}{|llll|}
\hline $\begin{array}{l}\text { Work Time Perception } \\
\text { Dimension Variables }\end{array}$ & Mean & St.dev & Meaning \\
Work time discipline & 3.63 & 1.03 & High \\
Work time incentive & 3.57 & 1.12 & High \\
Work time knowledge & 3.94 & 1.08 & High \\
Work time commitment & 3.05 & 1.16 & Fair \\
& & & \\
Work Satisfaction & Mean & St.dev & \\
Dimension Variables & & & \\
Self-esteem & 4.39 & 0.80 & High \\
Self-efficacy & 4.31 & 0.73 & High \\
Locus of control & 4.15 & 0.765 & High \\
Neuroticism & 3.69 & 0.88 & High \\
$\mathrm{N}=320$ & & & \\
\hline
\end{tabular}

Most respondents have a high perception of work satisfaction. Based on the calculation results, the majority of employees have high work satisfaction on self-esteem dimensions, self-efficacy dimensions, and the locus of control dimensions. The respondents have a lower score in neuroticism dimensions, but the score is quite close to the high margins. These findings confirm that highly educated workers have a relatively high level of anxiety. Since they have relatively long working time, this finding also confirms that longer work hours do put employees at a higher risk of distress. Based on the result of the index scoring from both of the test variables, we conclude that higher work 
time perception can lead to higher work satisfaction.

Table 5: Test variables index values

\begin{tabular}{|lcc|}
\hline Test Variables & Mean & St.dev \\
$\begin{array}{l}\text { Work Time Perception } \\
\text { Variable }\end{array}$ & 3.39 & 0.92 \\
$\begin{array}{l}\text { Work Satisfaction } \\
\text { Variable }\end{array}$ & 3.94 & 0.72 \\
$\mathrm{~N}=320$ & & \\
\hline
\end{tabular}

The descriptive analysis from this survey is consistent with the conclusion of most previous studies on the meaning of worktime for workers. Employees prefer shorter working time. This finding also confirms the workers' perspective on the flexibility of work time. They perceived work time as the time they spent at the office to do activities that are related with their work. Therefore, working overtime means the time that is spent to do work after official work hours, no matter where it takes place, either in the office or other places. Thus, the ability to complete work task in the office, and not bringing work to home also supports their work satisfaction.

\section{Table 6: Linearity Test}

\begin{tabular}{|c|c|c|}
\hline Test & F & sig \\
\hline Linearity & 59.1188 & $0.00^{* *}$ \\
\hline $\begin{array}{c}\text { Deviation from } \\
\text { Linearity }\end{array}$ & 10.5 & 0.027 \\
$p<.01 ;^{*} p<0.05 ; * *$
\end{tabular}

We run a linearity test to confirm the model of relationship between work time perception variable and work satisfaction. The result shows that the Linearity $p$ value is lower than 0.05 but the deviation from linearity $p$ value is lower than 0.05 which means that the assumption of linearity model is not fully satisfied. Thus, further analysis to test the linear model relationship is needed. We proceed to examine how exactly employees' work time perception influences their work satisfaction by dividing work time perception variable to two categories using its mean value as the reference of separation. The model summary of the regression analysis is depicted in table 7 .

Table 7: The Regression Model

\begin{tabular}{|l|l|l|l|l|c|}
\hline Predictor & $\mathrm{R}^{2}$ & $\mathrm{~F}$ & $\mathrm{~B}$ & $\mathrm{SE} \mathrm{B}$ & $\beta$ \\
\hline $\begin{array}{l}\text { Higher Perception of } \\
\text { Working Time }\end{array}$ & .141 & $26.416^{* *}$ & 0.638 & .124 & $0.375^{* *}$ \\
\hline $\begin{array}{l}\text { Lower Perception of } \\
\text { Working Time }\end{array}$ & .004 & .675 & .093 & .113 & .066 \\
\hline Work Time Perception & .133 & $48.659^{* *}$ & .355 & .051 & $.364^{* *}$ \\
\hline
\end{tabular}

The test on the relationship model between two variables concludes that the work time perception variable only influences work satisfaction when it is perceived positively by the respondent. Based on the regression model, we interpret the appropriate model 
as follows: the perception of work time affects job satisfaction linearly. The model indicates the strength of the relationship between two variables is low, with an Rvalue of 0.364 . The $R^{2}$ value indicates that the work time perception explains $13 \%$ of their work satisfaction. Although work time perception only explains a limited amount of work satisfaction, the model is significant to represent the relationship between the two variables empirically.

The regression model developed from the survey results indicates a linear relationship between the test variables. It is reasonable to conclude that the higher attention of employees to their working time, the higher their work satisfaction would become. This finding is different from the group theory that stated working time has a nonlinear influence on employees' productivity (Beherens, 2013; Bannai and Tamakoshi, 2014). A linear model is more appropriate to explain the relationship between employees' working time perception and work satisfaction. There are two reasons that explain this difference. First, the perception of work time is more complex than merely the number of hours spent on work. Working time perception is a set of values composed from incentives, knowledge, discipline, and commitment regarding the working time. Each employee perceived the four components based on their personality. These multi-dimensional measurements can accommodate the contributions of the four factors which the employees consider when they allocate their daily time for work-related activities.

Second, this research also demonstrates how work satisfaction could serve as a predictor of how workers respond to management flexibility. Employees are adapting to flexible work settings that are applied to serve employers' interests more than theirs'. A management culture with low trust has intensive control of employee behaviour (Peetz, 2019). Management replaces hourly overtime wages with fixed monthly performance incentives. This makes employees pursue to meet all requirements to get a full incentive from their work, including working overtime. This phenomenon is becoming more intriguing because at an individual-level each employee enjoys wage increases, but at the aggregate level, the employee's productivity decreases.

Workers' adaptation to working time arrangement is reflected in the neuroticism dimensions. Based on the survey finding, the neuroticism dimension has the lowest value among the four dimensions of work satisfaction. These findings indicate a high intensity of management in regulating employees' behaviour at work. Thus, workers understand that working hours are directly related to their income, so they are willing to work for a long time. However, long working hours are still limited only when they work in the office. Workers do not take their work home, so the time allocation for work, family, and recreation remains strictly compartmentalized.

\section{Conclusion}

A high-performance working system in a modern management system provides flexibility for work settings for employees. The implementation of this type of flexible work setting has created what is called numerical flexibility, which is applied by arranging employees' working time. Although every worker bounded by formal provisions enacted by their respective organizations, the respondents in this research responded differently to their working time setting arrangement.

Working time is significant because it is part of the daily lives of workers. The working time perception refers to the division of time allocation in one day, namely for work, family, and recreation. Moreover, work satisfaction can provide crucial information about the meaning of work time in the life of a worker.

Based on the research findings, there are several things to note between the effect of work time and work satisfaction:

1. The working time perception is more than mere knowledge about time. In a high-performance working system management, work time has become an integral part of the remuneration system. Thus, workers also anticipate the incentive that they could receive from the amount of time they spend at work. It generates a complex 
perception that involves knowledge of benefit and behaviour to achieve their interest.

2. Work time perception has a relationship with moderate intensity on work satisfaction. The nature of the relationship tends to be linear: the higher the working time perception, the higher the work satisfaction of an employee would become.

3. The majority of respondents involved in this survey were workers with a tertiary education background. So, it is reasonable to assume that they are part of the blue-collar worker group that has relative freedom to determine their work arrangements. By considering the link between their working time perception, and their work satisfaction, the finding of this study supports the theory of highperformance working system, which suggests that discretion for workers would raise their performance.

\section{References}

- Azwir, Hery Hamdi, and Satriawan, Heru. 2018. Analisis jam kerja efektif dalam upaya peningkatan produktivitas tenaga kerja dengan metode PDCA di PT NMI. Spektrum Industri. Vol 16. No.1 hlm 1-110. Retrieved from http://doi.org/10.12928/si.v16i1.978 $\underline{1}$

- Baihaqki, Umar. Jahja, Rusfadia S. (2019). The Influence of Years of Service to Teachers Perception of Their Precaious Condition: A Suryvey of Nonpermanent teachers working at 10 state junior high schools in Jakarta. Journal of Southeast Asian Research. Vol 2019 (2019) pp12 retrefed from http://doi.org/10.5171/2019.849196

- $\quad$ Bannai, Akira., Tamakoshi, Akiko. 2014. The association between long working hours and health: A systematic review of epidemiological evidence. Scandinavian Journal of Work, Environment \& Health. Vol 40 (1) pg. 518 retrieved from https://www.jstor.org/stable/431879

$\underline{83}$

- Bartling, Björn. Fehr, Ernst. and Schmidt, Klaus M. 2013. discretion, productivity, and work satisfaction. Journal of Institutional and Theoretical Economics, Vol 169 (1). pp 4 - 22, http://doi.org/10.1628/093245613X6 $\underline{60357}$

- Boschetto, Barbara. De Rosa, Eugenia, and Marini, Cristiano. (2016). WORKRELATED STRESS AND ASSOCIATED FACTORS IN ITALY: A COMPARISON BEFORE AND DURING THE ECONOMIC CRISIS. Rivista Internazionale di Scienze Sociali, Anno 124, (3/4). Special Issue on "Health and Economics". pp. 283300. Retriefed from https://www.jstor.org/stable/261515 79

- Burchielli, Rosaria. Bartram, Timothy, and Thanacoody, Rani. 2008. WorkFamily Balance or Greedy Organizations?. Relations Industrielles / Industrial Relations, Vol. 63 (1). pp. 108133

- Clark, Malissa A., Michel, Jesse S., Early, Rebecca J., Baltes, Boris B. (2014). Strategies for coping with work stressors and family stressors: Scale Development and Validation. Journal of Business and Psychology, Vol. 29 (4) pp. 617-638 https://doi.org/10.1007/s10869-0149356-7

- Frazier, M.L., Gooty, M.L., Little, L.M., and Nelson, D.L. (2015). Employee Attachment: Implications for Supervisor Trustworthiness and Trust. Journal of Business and Psychology. Vol. 30 (2) pp. 373-386

- Garnero, Andrea. Kampelmann, stephan. and rycx, francois. 2014. Parttime work, wages, and productivity: evidence from Belgian Matched Panel Data. Industrial \& Labor Relations Review. Vol 67(3). pp 926-954 retrieved from http://doi.org/10.1177/00197939145 $\underline{37456}$

- $\quad$ Grint, Keith. Nixon, Darren. 2015. The Sociology of Work. Cambridge. UK. Polity Press

- Hill, E. Jeffrey., Märtinson, Vjollca., and Ferris, Maria. (2004). New-Concept 
Part-Time Employment as a WorkFamily Adaptive Strategy for Women Professionls with Small Children. Family Relations. Vol. 53 (3). pp 282292 https://doi.org/10.1111/j.00222445.2004.0004.x

- Jackie Ford and David Collinson. (2011). In search of the perfect manager? Work-life balance and managerial work. Work, Employment \& Society. Vol. 25 (2). pp. 257-273. https://doi.org/10.1177/0950017011 398895

- $\quad$ Kelly, E.L., Moen, P., Oakes, J.M., Fan, W., Okechukwu, C., Davis, K.D., Hammer, L.B., Kossek, E.E., King, R.B., Hanson, G.C., Mierzwa, F., and Casper, L.M. (2014). Changing Work and WorkFamily Conflict: Evidence from the Work, Family, and Health Network. American Sociological Review, Vol. 79. (3). pp. 485-516 https://doi.org/10.1177/0003122414 531435

- KÜNN-NELEN, A., DE GRIP, A., \& FOUARGE, D. (2013). IS PART-TIME EMPLOYMENT BENEFICIAL FOR FIRM PRODUCTIVITY? ILR Review, 66(5), 1172-1191. Retrieved February 11, 2020, www.jstor.org/stable/24369576

- Mitchell, Terence R., Smyser, Charles M., and Stan E. Weed. (1975). Locus of Control: Supervision and Work Satisfaction. The Academy of Management Journal. Vol. 18 (3). pp. 623-631

http://doi.org/10.2307/255692

- Moazami-Goodarzi, Ali., Nurmi, JariErik. Mauno, Saija Mauno, and Rantanen, Johanna. (2015). CrossLagged Relations Between WorkFamily Enrichment, Vigor at Work, and Core Self- evaluations: A Three-Wave Study. Journal of Business and Psychology, Vol. 30 (3). pp. 473-482. https://doi.org/10.1007/s10869-0149376-3

- Nätti, J., Oinas, T., Anttila, T. (2015). Time pressure, working time control and long-term sickness absence. Occupational and Environmental Medicine. Vol 72 (4). pp 265-270

- O'Carroll, Ailee. (2015). Working Time, Knowledge Work and Post-Industrial
Society: upredictdable work Palgrave Macmillan. New York https://doi.org/DOI 10.1057/9781137318480

- $\quad$ Okulicz-Kozaryn, A., Golden, L. (2018). Happiness is flexitime. Applied Research Quality Life. Vol 13. Pp 355-369

- Peetz, David. (2019). The Realities and Futures of Work. ANU Press. Canberra

- $\quad$ Peng, Yuwen., and Mao, Chao. (2015). The Impact of Person-Job Fit on Job Satisfaction: The Mediator Role of Self Efficacy. Social Indicators Research, Vol. 121, No. 3 (April (II) 2015), pp. 805813. https://doi.org/10.1007/s11205014-0659-x

- Qingguo Zhai, Margaret Lindorff and Brian Cooper. (2013). Workplace Guanxi: Its Dispositional Antecedents and Mediating Role in the AffectivityJob Satisfaction Relationship. Journal of Business Ethics, Vol. 117 (3), pp. 541551. https://doi.org/10.1007/s10551012-1544-7

- $\quad$ Shogren, K.A., Wehmeyer, M.L., Palmer, S. B., Forber, A.J., Little, T.J., and Lopez, S. (2015). Causal Agency Theory: Reconceptualizing a Functional Model of Self-Determination. Education and Training in Autism and Developmental Disabilities. Vol. 50 (3). pp. 251-263

- Surachman, Eman. (2016). Manajemen Pendidikan-Tenaga Kependidikan. Laboratorium Sosiologi UNJ. Jakarta

- Timothy A. Judge. Joyce E. Bono, and Edwin A. Locke. (2000). Personality and Job Satisfaction: The Mediating Role of Job Characteristics. Journal of Applied Psychology. Vol. 85 (2). Pp 237-249. Retrieved http://doi.org/10.1037//0021$\underline{9010.85 .2 .237}$

- Vielers, Rudi., Münderlein, Maria., and Koster, Ferry. (2013). Part-time work and work hour preferences: an international comparison. European Sociological Review. Volume 30 (1). pg. 76-89.

https://doi.org/10.1093/esr/jct023

- Voydanoff, Patricia. (2014). The Effects of Work Demands and Resources on Work-to-Family Conflict and Facilitation. Journal of Marriage and Family, Vol. 66 (2). pp. 398-412. 
https://doi.org/10.1111/j.17413737.2004.00028.x

- Wanrooy, Brigid van., Wilson, S. (2006). Convincing the toilers? Dilemmas of long working hours in Australia. Work, Employment \& Society. volume 20(2). pp 349-368 retrieved from https://doi.org/10.1177/0950017006 $\underline{064274}$
- Watson, Tony J. 2006. Sociology, Work and Industry $5^{\text {th }}$ edition. Routledge. New York

- Yeh, Hsiu-Jen. 2015. Job demands, job resources, and job satisfaction in East Asia. Social Indicators Research, Vol. 121 (1). Pp: 47-60. Retrieved from http://doi.org/10.1007/s11205-014$\underline{0631-9}$ 